\title{
Editorial: PVT1 in Cancer
}

\author{
Olorunseun O. Ogunwobi ${ }^{1 *}$ and Miguel F. Segura ${ }^{2}$ \\ ${ }^{1}$ Department of Biological Sciences, Hunter College of The City University of New York, New York, NY, United States, \\ 2 Laboratory of Translational Research in Child and Adolescent Cancer, Hospital Universitari Vall d'Hebron, Vall d'Hebron \\ Institut de Recerca, VHIR, Universitat Autònoma de Barcelona, Barcelona, Spain
}

Keywords: PVT1, cancer, long non-coding RNA, non-coding RNA, chromosome 8q24

\section{Editorial on the Research Topic}

\section{PVT1 in Cancer}

The plasmacytoma variant translocation 1 (PVT1) gene is located at human chromosome 8q24, downstream of the well-known c-MYC oncogene (1). As chromosome 8q24 is a chromosomal region of genomic instability, it is not surprising that PVT1 was discovered in the context of cancer. PVT1 is now known to be dysregulated in non-cancerous diseases such as kidney disease (including diabetic nephropathy) (2), cardiac hypertrophy (3), vitiligo (4), osteoarthritis (5), and asthma (6). However, PVT1 is much better established to be dysregulated in a wide variety of cancers including plasmacytomas $(7,8)$, lymphomas $(9,10)$, leukemias $(11,12)$, sarcomas (including osteosarcoma) $(13,14)$, ovarian cancer $(15,16)$, breast cancer $(16,17)$, lung cancer $(18,19)$, astrocytomas (20), pancreatic cancer (21, 22), prostate cancer (23-26), cholangiocarcinoma (27), gliomas (28), medulloblastoma (29), mesothelioma (30), colorectal cancer (31), gastric cancer (32), hepatocellular carcinoma $(33,34)$, thyroid cancer (35), bladder cancer (36), renal cell carcinoma $(37,38)$, cervical cancer (39), esophageal cancer (40), melanoma (41), endometrial cancer (42, 43), non-small cell lung cancer $(44,45)$, and cutaneous squamous cell carcinoma $(46,47)$.

PVT1 has at least 12 annotated exons: exon $1 \mathrm{~A}$, exon $1 \mathrm{~B}$, exon $1 \mathrm{C}$, exon 2 , exon $3 \mathrm{~A}$, exon $3 \mathrm{~B}$, exon $4 \mathrm{~A}$, exon $4 \mathrm{~B}$, exon 5 , exon 6 , exon 7 , exon 8 , and exon 9 (1). And it encodes six annotated microRNAs (miRNAs): miR-1204, miR-1205, miR-1206, miR-1207-3p, miR-1207-5p, and miR-1208 (48). PVT1 is expressed in the various organs throughout the human body. There is progressively increasing evidence that distinct PVT1 exons, and PVT1-encoded miRNAs have significant biological functions, as discussed in the well-written articles included in our Research Topic entitled "PVT1 in Cancer." In addition, there is evidence of alternative splicing at the PVT1 gene, resulting in at least 25 annotated PVT1 transcript variants (Martinez-Barriocanal et al.). As noted in several of the papers published in the Research Topic "PVT1 in Cancer," PVT1 induces cancer development and progression via a variety of biological mechanisms including but not limited to miRNA regulation (Wang et al.), and as a competing endogenous RNA (ceRNA) (Ogunwobi and Kumar).

The articles included in the Research Topic "PVT1 in Cancer" are particularly interesting because they highlight the clinical relevance and potential clinical applications of PVT1 in cancer. For example, the article by Boloix et al. discusses the potential prognostic applications and the potential to target PVT1 for therapeutic applications in pediatric cancers. All of the other articles discuss potential clinical applications in a variety of adult cancers. Notably, Ogunwobi and Kumar identify PVT1 as a mediator of cancer chemoresistance. Thus, targeting PVT1 may have a future role in the treatment of many highly lethal cancers such as pancreatic cancer, and neuroendocrine prostate cancer where chemoresistance is common. 


\section{AUTHOR CONTRIBUTIONS}

All authors listed have made a substantial, direct and intellectual contribution to the work, and approved it for publication.

\section{REFERENCES}

1. Huppi K, Pitt JJ, Wahlberg BM, Caplen NJ. The $8 \mathrm{q} 24$ gene desert: an oasis of non-coding transcriptional activity. Front Genet. (2012) 3:69. doi: 10.3389/fgene.2012.00069

2. Alvarez ML, DiStefano JK. Functional characterization of the plasmacytoma variant translocation 1 gene (PVT1) in diabetic nephropathy. PLoS ONE. (2011) 6:e18671. doi: 10.1371/journal.pone.0018671

3. Yu YH, Hu ZY, Li MH, Li B, Wang ZM, Chen SL. Cardiac hypertrophy is positively regulated by long non-coding RNA PVT1. Int J Clin Exp Pathol. (2015) 8:2582-9.

4. Ben S, Jin Y, Santorico SA, Spritz RA. Genome-wide association of PVT1 with Vitiligo. J Invest Dermatol. (2018) 138:1884-6. doi: 10.1016/j.jid.2018.02.025

5. Li Y, Li S, Luo Y, Liu Y, Yu N. LncRNA PVT1 regulates chondrocyte apoptosis in osteoarthritis by acting as a sponge for miR-488-3p. DNA Cell Biol. (2017) 36:571-80. doi: 10.1089/dna.2017.3678

6. Austin PJ, Tsitsiou E, Boardman C, Jones SW, Lindsay MA, Adcock IM, et al. Transcriptional profiling identifies the long noncoding RNA plasmacytoma variant translocation (PVT1) as a novel regulator of the asthmatic phenotype in human airway smooth muscle. J Allergy Clin Immunol. (2017) 139:780-9. doi: 10.1016/j.jaci.2016.06.014

7. Webb E, Adams JM, Cory S. Variant $(6 ; 15)$ translocation in a murine plasmacytoma occurs near an immunoglobulin kappa gene but far from the myc oncogene. Nature. (1984) 312:777-9. doi: 10.1038/312777a0

8. Cory S, Graham M, Webb E, Corcoran L, Adams JM. Variant $(6 ; 15)$ translocations in murine plasmacytomas involve a chromosome 15 locus at least $72 \mathrm{~kb}$ from the c-myc oncogene. EMBO J. (1985) 4:675-81. doi: 10.1002/j.1460-2075.1985.tb03682.x

9. Huppi K, Siwarski D. Chimeric transcripts with an open reading frame are generated as a result of translocation to the Pvt-1 region in mouse B-cell tumors. Int J Cancer. (1994) 59:848-51. doi: 10.1002/ijc.2910590623

10. Graham M, Adams JM. Chromosome 8 breakpoint far 3' of the cmyc oncogene in a Burkitt's lymphoma $2 ; 8$ variant translocation is equivalent to the murine pvt-1 locus. EMBO J. (1986) 5:2845-51. doi: 10.1002/j.1460-2075.1986.tb04578.x

11. Yazdi N, Houshmand M, Atashi A, Kazemi A, Najmedini AA, Zarif MN. Long noncoding RNA PVT1: potential oncogene in the development of acute lymphoblastic leukemia. Turk J Biol. (2018) 42:405-13. doi: 10.3906/biy-1801-46

12. Zeng C, Yu X, Lai J, Yang L, Chen S, Li Y. Overexpression of the long non-coding RNA PVT1 is correlated with leukemic cell proliferation in acute promyelocytic leukemia. J Hematol Oncol. (2015) 8:126. doi: 10.1186/s13045-015-0223-4

13. Liu J, Li R, Liao $\mathrm{X}, \mathrm{Hu} \mathrm{B}, \mathrm{Yu}$ J. Comprehensive investigation of the clinical significance and molecular mechanisms of plasmacytoma variant translocation 1 in sarcoma using genome-wide RNA sequencing data. $J$ Cancer. (2019) 10:4961-77. doi: 10.7150/jca.31675

14. Zhou Q, Chen F, Zhao J, Li B, Liang Y, Pan W, et al. Long noncoding RNA PVT1 promotes osteosarcoma development by acting as a molecular sponge to regulate miR-195. Oncotarget. (2016) 7:82620-33. doi: 10.18632/oncotarget.13012

15. Chen Y, Du H, Bao L, Liu W. LncRNA PVT1 promotes ovarian cancer progression by silencing miR-214. Cancer Biol Med. (2018) 15:238-50. doi: 10.20892/j.issn.2095-3941.2017.0174

16. Guan Y, Kuo WL, Stilwell JL, Takano H, Lapuk AV, Fridlyand J, et al. Amplification of PVT1 contributes to the pathophysiology of ovarian and breast cancer. Clin Cancer Res. (2007) 13:5745-55. doi: 10.1158/1078-0432.CCR06-2882

\section{FUNDING}

OO was supported by National Cancer Institute grant \# U54CA221704.

17. Tang J, Li Y, Sang Y, Yu B, Lv D, Zhang W, et al. LncRNA PVT1 regulates triple-negative breast cancer through KLF5/beta-catenin signaling. Oncogene. (2018) 37:4723-34. doi: 10.1038/s41388-018-0310-4

18. Guo D, Wang Y, Ren K, Han X. Knockdown of LncRNA PVT1 inhibits tumorigenesis in non-small-cell lung cancer by regulating miR-497 expression. Exp Cell Res. (2018) 362:172-9. doi: 10.1016/j.yexcr.2017.11.014

19. Chen W, Zhu H, Yin L, Wang T, Wu J, Xu J, et al. IncRNA-PVT1 facilitates invasion through upregulation of MMP9 in nonsmall cell lung cancer cell. DNA Cell Biol. (2017) 36:787-93. doi: 10.1089/dna.2017.3725

20. Schiffman JD, Hodgson JG, VandenBerg SR, Flaherty P, Polley MY, Yu M, et al. Oncogenic BRAF mutation with CDKN2A inactivation is characteristic of a subset of pediatric malignant astrocytomas. Cancer Res. (2010) 70:512-9. doi: 10.1158/0008-5472.CAN-09-1851

21. Zhao L, Kong H, Sun H, Chen Z, Chen B, Zhou M. LncRNA-PVT1 promotes pancreatic cancer cells proliferation and migration through acting as a molecular sponge to regulate miR-448. J Cell Physiol. (2018) 233:4044-55. doi: $10.1002 /$ jcp. 26072

22. You L, Wang H, Yang G, Zhao F, Zhang J, Liu Z, et al. Gemcitabine exhibits a suppressive effect on pancreatic cancer cell growth by regulating processing of PVT1 to miR1207. Mol Oncol. (2018) 12:2147-64. doi: 10.1002/1878-0261.12393

23. Ilboudo A, Chouhan J, McNeil BK, Osborne JR, Ogunwobi OO. PVT1 Exon 9: a potential biomarker of aggressive prostate cancer? Int J Environ Res Public Health. (2015) 13:ijerph13010012. doi: 10.3390/ijerph13010012

24. Pal G, Huaman J, Levine F, Orunmuyi A, Olapade-Olaopa EO, Onagoruwa OT, et al. Long noncoding RNA from PVT1 exon 9 is overexpressed in prostate cancer and induces malignant transformation and castration resistance in prostate epithelial cells. Genes. (2019) 10:964. doi: 10.3390/genes10120964

25. Orunmuyi A, Ilboudo A, Ogun O, Bach C, Adebayo S, Salako A, et al. PVT1 exons $4 \mathrm{~A}, 4 \mathrm{~B}$, and 9 are overexpressed in aggressive prostate cancer, and PVT1 exon $4 \mathrm{~B}$ may distinguish between indolent and aggressive prostate cancer. Cancer Res. (2017) 77 (13 Suppl.):3507. doi: 10.1158/1538-7445.AM2017-3507

26. Pal G, Di L, Orunmuyi A, Olapade-Olaopa EO, Qiu W, Ogunwobi OO. Population differentiation at the PVT1 gene locus: implications for prostate cancer. G3 (Bethesda). (2020) 10:2257-64. doi: 10.1534/g3.120.401291

27. Chapman MH, Tidswell R, Dooley JS, Sandanayake NS, Cerec V, Deheragoda $\mathrm{M}$, et al. Whole genome RNA expression profiling of endoscopic biliary brushings provides data suitable for biomarker discovery in cholangiocarcinoma. J Hepatol. (2012) 56:877-85. doi: 10.1016/j.jhep.2011.10.022

28. Zhang Y, Yang G, Luo Y. Long non-coding RNA PVT1 promotes glioma cell proliferation and invasion by targeting miR-200a. Exp Ther Med. (2019) 17:1337-45. doi: 10.3892/etm.2018.7083

29. Northcott PA, Shih DJ, Peacock J, Garzia L, Morrissy AS, Zichner T, et al. Subgroup-specific structural variation across 1,000 medulloblastoma genomes. Nature. (2012) 488:49-56. doi: 10.1038/nature11327

30. Riquelme E, Suraokar MB, Rodriguez J, Mino B, Lin HY, Rice DC, et al. Frequent coamplification and cooperation between C-MYC and PVT1 oncogenes promote malignant pleural mesothelioma. J Thorac Oncol. (2014) 9:998-1007. doi: 10.1097/JTO.0000000000000202

31. Wu H, Wei M, Jiang X, Tan J, Xu W, Fan X, et al. lncRNA PVT1 promotes tumorigenesis of colorectal cancer by stabilizing miR-16-5p and interacting with the VEGFA/VEGFR1/AKT axis. Mol Ther Nucleic Acids. (2020) 20:43850. doi: 10.1016/j.omtn.2020.03.006

32. Xu MD, Wang Y, Weng W, Wei P, Qi P, Zhang Q, et al. A positive feedback loop of lncRNA-PVT1 and FOXM1 facilitates gastric cancer growth and invasion. Clin Cancer Res. (2017) 23:2071-80. doi: 10.1158/1078-0432.CCR-16-0742 
33. Gou X, Zhao X, Wang Z. Long noncoding RNA PVT1 promotes hepatocellular carcinoma progression through regulating miR-214. Cancer Biomark. (2017) 20:511-9. doi: 10.3233/CBM-170331

34. Lan T, Yan X, Li Z, Xu X, Mao Q, Ma W, et al. Long non-coding RNA PVT1 serves as a competing endogenous RNA for miR-186-5p to promote the tumorigenesis and metastasis of hepatocellular carcinoma. Tumour Biol. (2017) 39:1010428317705338. doi: 10.1177/1010428317705338

35. Zhang R, Hardin H, Huang W, Buehler D, Lloyd RV. Long non-coding RNA Linc-ROR is upregulated in papillary thyroid carcinoma. Endocr Pathol. (2018) 29:1-8. doi: 10.1007/s12022-017-9507-2

36. Tian Z, Cao S, Li C, Xu M, Wei H, Yang H, et al. LncRNA PVT1 regulates growth, migration, and invasion of bladder cancer by miR-31/ CDK1. J Cell Physiol. (2019) 234:4799-811. doi: 10.1002/jcp.27279

37. Zou B, Wang D, Xu K, Liu JL, Yuan DY, Meng Z, et al. Prognostic value of long non-coding RNA plasmacytoma variant translocation1 in human solid tumors: a meta-analysis. Medicine. (2019) 98:e16087. doi: 10.1097/MD.0000000000016087

38. Li W, Zheng Z, Chen H, Cai Y, Xie W. Knockdown of long non-coding RNA PVT1 induces apoptosis and cell cycle arrest in clear cell renal cell carcinoma through the epidermal growth factor receptor pathway. Oncol Lett. (2018) 15:7855-63. doi: 10.3892/ol.2018.8315

39. Iden M, Fye S, Li K, Chowdhury T, Ramchandran R, Rader JS. The lncRNA PVT1 contributes to the cervical cancer phenotype and associates with poor patient prognosis. PLoS ONE. (2016) 11:e0156274. doi: 10.1371/journal.pone.0156274

40. Li PD, Hu JL, Ma C, Ma H, Yao J, Chen LL, et al. Upregulation of the long non-coding RNA PVT1 promotes esophageal squamous cell carcinoma progression by acting as a molecular sponge of miR-203 and LASP1. Oncotarget. (2017) 8:34164-76. doi: 10.18632/oncotarget.15878

41. Chen L, Ma D, Li Y, Li X, Zhao L, Zhang J, et al. Effect of long non-coding RNA PVT1 on cell proliferation and migration in melanoma. Int J Mol Med. (2018) 41:1275-82. doi: 10.3892/ijmm.2017.3335

42. Xing TR, Chen P, Wu JM, Gao LL, Yang W, Cheng Y, et al. UPF1 participates in the progression of endometrial cancer by inhibiting the expression of lncRNA PVT1. Onco Targets Ther. (2020) 13:2103-14. doi: 10.2147/OTT.S233149
43. Kong F, Ma J, Yang H, Yang D, Wang C, Ma X. Long non-coding RNA PVT1 promotes malignancy in human endometrial carcinoma cells through negative regulation of miR-195-5p. Biochim Biophys Acta. (2018). doi: 10.1016/j.bbamcr.2018.07.008

44. Cui D, Yu CH, Liu M, Xia QQ, Zhang YF, Jiang WL. Long non-coding RNA PVT1 as a novel biomarker for diagnosis and prognosis of non-small cell lung cancer. Tumour Biol. (2016) 37:4127-34. doi: 10.1007/s13277-015-4261-x

45. Qiu C, Li S, Sun D, Yang S. IncRNA PVT1 accelerates progression of non-small cell lung cancer via targeting miRNA-526b/EZH2 regulatory loop. Oncol Lett. (2020) 19:1267-72. doi: 10.3892/ol.2019.11237

46. Das Mahapatra K, Pasquali L, Sondergaard JN, Lapins J, Nemeth IB, Baltas $\mathrm{E}$, et al. A comprehensive analysis of coding and non-coding transcriptomic changes in cutaneous squamous cell carcinoma. Sci Rep. (2020) 10:3637. doi: 10.1038/s41598-020-59660-6

47. Wu D, Li Y, Zhang H, Hu X. Knockdown of Lncrna PVT1 enhances radiosensitivity in non-small cell lung cancer by sponging Mir-195. Cell Physiol Biochem. (2017) 42:2453-66. doi: 10.1159/000480209

48. Huppi K, Volfovsky N, Runfola T, Jones TL, Mackiewicz M, Martin $\mathrm{SE}$, et al. The identification of microRNAs in a genomically unstable region of human chromosome 8q24. Mol Cancer Res. (2008) 6:212-21. doi: 10.1158/1541-7786.MCR-07-0105

Conflict of Interest: OO is a co-founder of NucleoBio, Inc., a City University of New York start-up biotechnology company.

The remaining author declares that the research was conducted in the absence of any commercial or financial relationships that could be construed as a potential conflict of interest.

Copyright (c) 2020 Ogunwobi and Segura. This is an open-access article distributed under the terms of the Creative Commons Attribution License (CC BY). The use, distribution or reproduction in other forums is permitted, provided the original author(s) and the copyright owner(s) are credited and that the original publication in this journal is cited, in accordance with accepted academic practice. No use, distribution or reproduction is permitted which does not comply with these terms. 